\title{
The Challenge of Crafting Institutions for the Commons: The Case of Community Forestry Support Programs in Mexico 2003-2008
}

\author{
Francisco Chapela \\ Northwest Mexico Program, The Christensen Fund, San Francisco, California 94107, USA
}

\begin{abstract}
Mexico forest tenure structure is known worldwide for its progressive approach of giving local communities full property rights to set a robust support to sustainable livelihoods in forested areas. Most forest areas in Mexico are owned by local communities either through the ejido, agrarian indigenous community or groups of small owners. In the last 30 years, many forest communities explored forest production at a commercial scale, creating their own communal forestry business and concurring to national markets with their timber and non-timber products. The socio-economical impacts of this approach were tremendous, steadily improving communities living standards. This success prompted rural organizations to ask the Mexican government to launch programs to expand the "community forestry" model. With international assistance from the World Bank and other agencies, the government of Mexico launched three different programs to foster forest commons: the Forest Conservation and Management Program, the Indigenous, Communities and Biodiversity Project and the Mexican part of the Mesoamerican Biological Corridor. Performance of these programs has been assessed through the World Bank evaluation framework, but the question about their environmental impact or even about their environmental sustainability and therefore their validity as national policies has been scantily explored and practically not debated. To contribute to answering these questions, the author made an extensive analysis of their impact over forest cover during the 2003-2008 period using land cover maps and correlated them with institutional development variables, building a social organization and collective action index (SOCAI), following Elinor Ostrom institutional analysis and development framework (IAD).
\end{abstract}

Key words: Biodiversity, forest policy, collective action, community conservation, economic valuation.

\section{Introduction}

Although most forests in the world are managed by government agencies, after years of experience showing how local people depend on forest resources for their livelihoods and become the best steward of the ecosystem that nurtures them at global level, there is a slight trend towards giving local communities and indigenous peoples the right to manage their forests. Governments switch their role to become guardians of legality and public interest, instead of being involved in forest management and forest products elaboration and trade.

In contrast, forests in Mexico are owned mostly by

Corresponding author: Francisco Chapela, Ph.D., research fields: economics of natural resources, institutional economics and common pool resources management. local, forest-dependent communities. This is because firstly indigenous communities in Mexico have a long record of interdependency with their biodiverse forest environment for their water, game, wild plants, fiber, medicines and timber [1]. Secondly, since Mexico became an independent nation in the 19th century, in fact, recognition of forest-local communities interdependency made the provision of suitable territories to local indigenous and non-indigenous peoples an important political issue that decided political stability, thus allowing that indigenous agricultural and political institutions coexist with the colonial regime [2]. Thirdly, after a land grabbing process that accelerated in late 19th century, an internal struggle known as the Mexican revolution and a land redistribution process started after an agrarian 
reform in 1917. The land re-distribution process continued until 1990, and for some reason, several ideals are still pending to become reality (for example, Mexican revolution [3]). Today, most forests in Mexico are owned and managed by different types of forest communities. As a result, many of them with indigenous backgrounds and occupying traditional lands, including agrarian communities, ejidos and clusters of small individual owners, have developed effective forest steward systems [4]. In spite of this historic trend, in recent years, there is a process of privatization of forest lands through the extinction of indigenous property rights [5] (Fig. 1).

In the last 30 years, many forest communities explored forest production at a commercial scale, creating their own communal forestry business and successfully concurring to the national markets with their timber and non-timber products [6]. The social and economical impacts of this approach were tremendous, steadily improving the living standards of communities with their own forestry businesses [7].

This success prompted rural organizations to ask

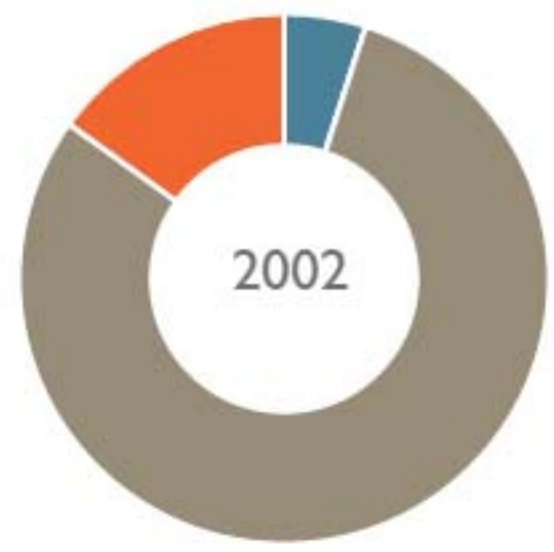

the Mexican government to launch programs to expand the "community forestry" model as much as possible. With international assistance from the World Bank and other agencies, the government of Mexico launched three different programs to foster forest commons: the Indigenous and Communities Biodiversity Project (COINBIO) [8], the Mexican part of the Mesoamerican Biological Corridor (CBM) [9] and the Forest Conservation and Management Program (PROCYMAF) [10].

These programs with a finance of millions of dollars can be seen as a virtual social and environmental experiment. The lessons learned from this high-scale virtual experiment on institutional design for community forestry in Mexico, show the possibilities to include innovative elements into the national biodiversity strategy.

The social and economical impact of these programs has been documented in their respective evaluations [11-13], but the question about their environmental impact or even about their environmental sustainability and therefore their validity as national

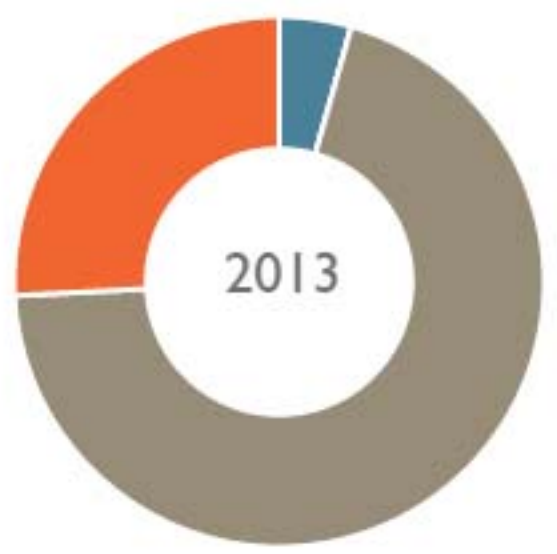

Government administered

Designated for IPS and local communities

Owned by IPS and local communities

Owned by individuals and firms
2002

2.75

Fig. 1 Forest ownership in Mexico.

Source: Rights and Resources Initiative, 2015 [5]. 
policies, has been scantily explored and practically not debated. To contribute to answer these questions, the author compared 2003 and 2008 land use maps, which was the core time of execution of these three programs, to assess their effectiveness in protecting forests, assess their respective cost/effectiveness ratios (C/E) and explore their correlation with institutional development variables, following Elinor Ostrom institutional analysis and development framework (IAD) [14-16], constructing an index called "social organization and collective action index (SOCAI)". The study considered 2,070 cases of forest communities, covering 9 million ha in South Mexico. It compared the $\mathrm{C} / \mathrm{E}$ of the three programs analyzed, and contrasted them with areas with no such programs and the nearest government declared natural protected areas (NPAs) to comprehensively show their potential as public policies. To explore possible explanation of the different $\mathrm{C} / \mathrm{E}$ observed, interviews were realized to local peoples at each zone studied, to estimate SOCAI at each place. The results were used to suggest some institutional innovations for better biodiversity and forest-related policies.

\section{Materials and Methods}

Although born from a common quarry and all of them aiming to explore institutional arrangements to complement the traditional NPAs scheme, PROCYMAF, COINBIO and CBM had different objectives and therefore different institutional designs.

As shown in Table 1, the different programs had different institutional designs. This was because they had differently spelled goals and these differences corresponded to different theoretical and policy approaches. Basically, we can analyze different institutional designs in terms of the components, which they may have to promote social capital formation, and in terms of their belonging or not to government branches. The NPAs are explicitly designed to give government control over biologically sensitive areas, while CBM, PROCYMAF and COINBIO tried participatory approaches, which made them similar. CBM did not seek livelihoods enhancement as its primary goal and does not have local communities in its governance bodies. COINBIO had all the factors that we called "promoters of social capital". Today, the NPAs system is the mainstream approach to conservation in Mexico. CBM is still under operation, is not including enough promoters of social capital into its institutional design, and does not seem to be interested in doing so, in spite of accumulating evidences that their performance is well above from optimal. PROCYMAF and COINBIO ended as short-lived experiences that may inform the national biodiversity policy, although COINBIO is still slightly operational. The funds for this program have been scarce, while hundreds of million dollars are being directed to prevent forest communities to continue their stewardship role, through the so-called payment for environmental services program.

To analyze the environmental effectiveness of these programs in comparison to the traditional ANPs approach and to areas where these programs were absent,

Table 1 Community forestry-related programs' institutional designs.

\begin{tabular}{llllll}
\hline \multirow{2}{*}{ Program } & \multicolumn{4}{c}{ Promoters of social capital } \\
\cline { 2 - 6 } & Demand-driven & $\begin{array}{l}\text { Livelihoods } \\
\text { enhancement as } \\
\text { primary goal }\end{array}$ & $\begin{array}{l}\text { Local communities in } \\
\text { governance bodies }\end{array}$ & $\begin{array}{l}\text { Support to new } \\
\text { community } \\
\text { initiatives }\end{array}$ & $\begin{array}{l}\text { Linked to an } \\
\text { existing government } \\
\text { branch }\end{array}$ \\
\hline CBM & Yes & No & No & Yes & Yes \\
PROCYMAF & Yes & Yes & No & No & Yes \\
COINBIO & Yes & Yes & Yes & Yes & No \\
NPAs & No & No & No & No & Yes \\
\hline
\end{tabular}

Source: author's analysis based on programs official documents, interviews and field observations. 
2,070 communities covering 9,078,704 ha in South Mexico were chosen. The study analyzes their forest cover changes during the period 2003-2008 in which the programs studied were active. Communities with presence of CBM, COINBIO and PROCYMAF in Michoacan, Guerrero, Oaxaca, Chiapas, Tabasco, Campeche and Quintana Roo states were analyzed, as well as the closest ANPs and surrounding communities (Fig. 2 and Table 2).
Vegetation coverage change was analyzed based on digital maps produced by the National Statistics and Geography Institute (INEGI) for 2003 and 2008 $[17,18]$. This assured high consistence in the interpretation of spatial data near to the start of the programs and near to their end. Successful to avoid deforestation or increases in forest area when that happened, was considered as the "effectiveness" part of the $\mathrm{C} / \mathrm{E}$ ratio.

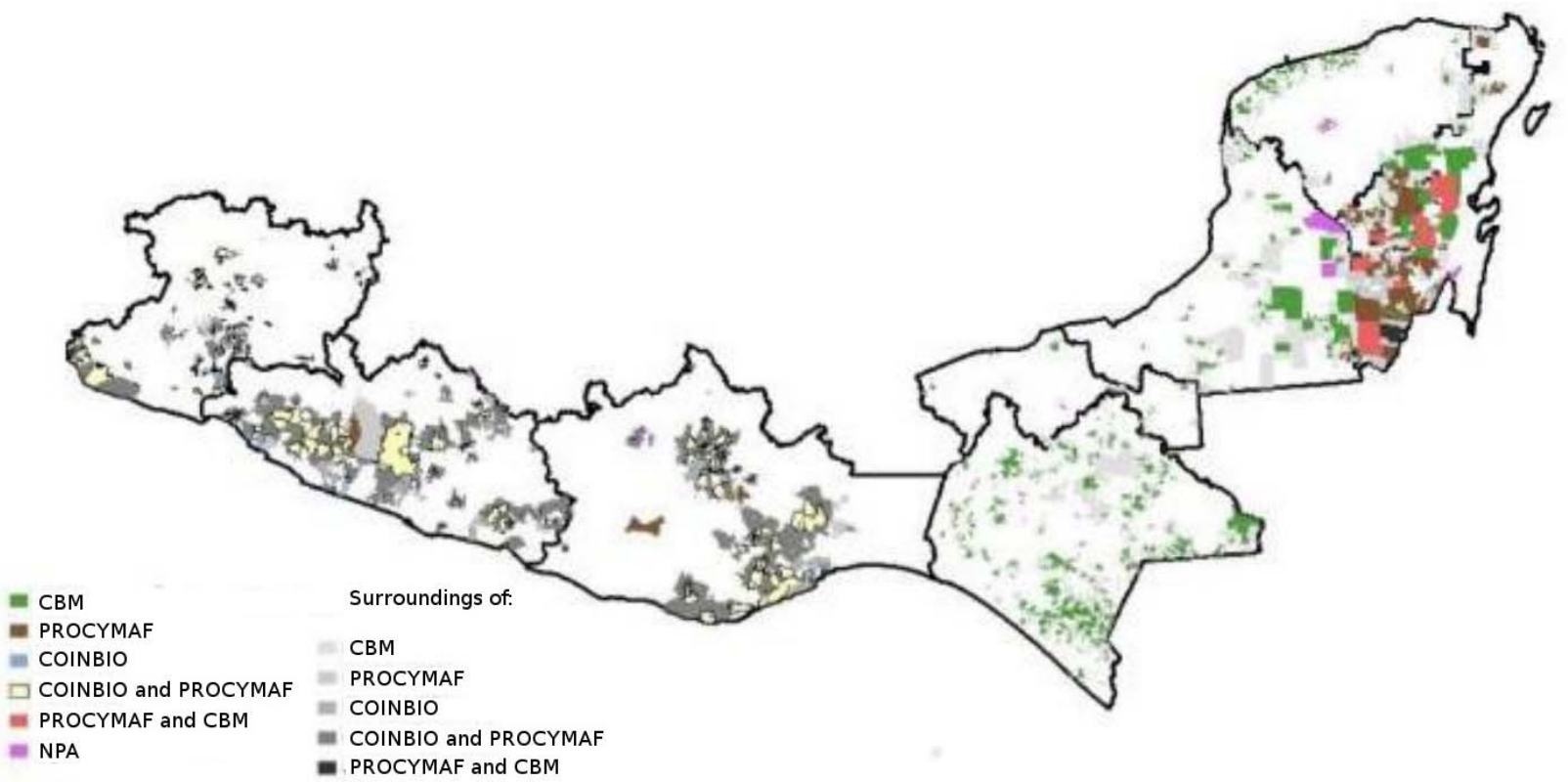

Fig. 2 Distribution of communities considered in the study at different programs areas: CBM, COINBIO, PROCYMAF, NPAs and surrounding communities in South Mexico.

Table 2 Number of communities and area studied.

\begin{tabular}{lll}
\hline Program & Communities (No.) & Area (ha) \\
\hline CBM & 376 & $1,402,122$ \\
PROCYMAF & 77 & 701,542 \\
COINBIO & 22 & 64,244 \\
PROCYMAF + CBM & 183 & $1,287,763$ \\
PROCYMAF + COINBIO & 22 & 404,818 \\
\hline Participatory programs total contrast programs & 680 & $3,860,489$ \\
\hline ANPs & 17 & 145,345 \\
CBM surroundings & 847 & $2,310,245$ \\
PROCYMAF surroundings & 82 & 531,830 \\
COINBIO surroundings & 53 & 201,364 \\
PROCYMAF + CBM surroundings & 379 & $1,959,949$ \\
PROCYMAF + COINBIO surroundings & 12 & 69,482 \\
\hline Contrast communities total & 1,390 & $5,218,215$ \\
\hline Total studied & 2,070 & $9,078,704$ \\
\hline
\end{tabular}


As seen in Table 3, the programs studied were supported by multilateral agencies with several million dollars each.

In addition to multilateral financing, the programs had co-finance from Mexican institutions, the total observed costs are shown in Table 4.

The costs of each program were considered to assess their $\mathrm{C} / \mathrm{E}$ ratio, in order to obtain an indicator of their suitability as a public policy. Costs were obtained as presented on official reports from the programs being analyzed. Thus, $\mathrm{C} / \mathrm{E}$ is expressed as the average cost of 1 ha effectively protected under the program being analyzed.

In addition, a subsample was selected to conduct semi-structured interviews with focal points to assess some Elinor Ostrom IAD indicators [19] and explore potential correlations between forest cover conservation effectiveness and social capital under different institutional approaches. Four communities under each program were randomly chosen to interview groups of 4-10 individuals, who have been part of community committees related to biodiversity conservation and were asked about their knowledge of these programs and their perceived benefits over biodiversity. Community social organization and collective action were assessed by asking about the existence of internal by-laws or regulations, provisions to regulate natural resources access and use, their communal lands use plans, community development plans, frequency of general assemblies of commoners, the existence of a community commission or body to deal with natural resources and biodiversity. A 30 items interview guide was used to conduct these semi-structured exercises.

Following Varughese's experience in Nepal [20], SOCAI was constructed as a 0-9 index, depending on the following aspects:

(1) Whether an internal by-law to regulate natural resources access and use exists;

(2) Whether a specialized biodiversity or natural resources commuity commission exists and is functional;

(3) Whether a communal land use plan is agreed by the community;

(4) Whether a community development plan is agreed by the community;

(5) Whether a general assembly combines regularly;

(6) Whether community representatives are renewed periodically;

(7) Whether functional mechanisms enforce communal regulations;

(8) Whether collective activities are organized to

Table 3 Multilateral finance to the programs studied.

\begin{tabular}{|c|c|c|c|c|c|}
\hline Program & $\begin{array}{l}\text { Multilateral finance } \\
\text { (million US dollars) }\end{array}$ & Execution period & Financed as & Financed by & Implemented by \\
\hline PROCYMAF & 21.3 & Jan. 2003-Dec. 2007 & Credit & World Bank & $\begin{array}{l}\text { National Forestry } \\
\text { Commission }\end{array}$ \\
\hline COINBIO & 7.5 & Jan. 2001-Jun. 2008 & Grant & $\begin{array}{l}\text { Global Environment Facility } \\
\text { through the World Bank }\end{array}$ & $\begin{array}{l}\text { National Development } \\
\text { Bank (NAFIN) }\end{array}$ \\
\hline CBM & 14.84 & Jan. 2001-Jun. 2008 & Grant & $\begin{array}{l}\text { Global Environment Facility } \\
\text { through the World Bank }\end{array}$ & $\begin{array}{l}\text { National Development } \\
\text { Bank (NAFIN) }\end{array}$ \\
\hline NPAs & 2.3 & Permanent & Grant & $\begin{array}{l}\text { Global Environment Facility } \\
\text { through the United Nations } \\
\text { Environment Program }\end{array}$ & $\begin{array}{l}\text { National Protected } \\
\text { Areas Commission }\end{array}$ \\
\hline
\end{tabular}

Table 4 Programs' total yearly costs (US dollars).

\begin{tabular}{llll}
\hline Program & Multilateral finance/year & Co-finance/year & Total yearly cost \\
\hline PROCYMAF & 4.26 & 1.52 & 5.78 \\
COINBIO & 1.50 & 2.24 & 3.74 \\
CBM & 2.12 & 12.56 & 14.68 \\
NPAs & 2.30 & 6.29 & 8.59 \\
\hline
\end{tabular}


manage and protect forests and biodiversity being regularly pursued;

(9) Whether community members are engaged in monitoring biodiversity and forest conservation.

\section{Results}

Changes in forest cover included a wide range from high deforestation to very low. In Guerrero and Oaxaca states, cases were recorded where forest cover even increased (Figs. 3-5). The overall conservation effect ranged from a net deforestation rate (-0.08\%/year) for CBM to a net strong forest coverage increase for COINBIO and PROCYMAF $(+0.52 \% /$ year and $+0.50 \% /$ year $)$ and a more modest increase $(0.46 \%)$ in forest cover for NPAs. A comparison of these values using a Welch test shows that COINBIO and PROCYMAF are significantly more effective $(P<0.10)$ in protecting forest cover than NPAs and highly significantly $(P<0.01)$ more effective than CBM. Considering each program forest cover conservation effectiveness, as shown by the author's own land-use change analysis and the costs of each of them and as recorded on their official reports, a wide spectrum of 2.83-8.61 C/E was observed, showing
CBM with the worst C/E ratio, PROCYMAF with the best and COINBIO and NPAs in the middle (Table 5).

In-field interviews allowed to estimate SOCAI and run correlation analysis, showing an interesting significant $(P<0.10)$ relation between SOCAI and $\mathrm{C} / \mathrm{E}$ ratio, with dramatic improvements in $\mathrm{C} / \mathrm{E}$ associated to higher levels of social organization and collective action (Table 6).

\section{Discussion}

In 1994, Ostrom et al. [21] showed empiric evidence, experimental work and theoretical analysis, and pointed out that common resources, such as forests or biodiversity, can be better managed if direct users are effectively engaged in setting the access, use and distribution rules and monitoring the outcomes of these rules to improve them. In the same line, in 1999, Agrawal and Gibson [22] pointed out that community conservation can indeed be an approach that may make conservation more effective, not because resources use is "communal", but because of institutions, i.e., sets of written or consuetudinary rules observed by common natural resources users to assure efficient use and successful regeneration. In 1999,

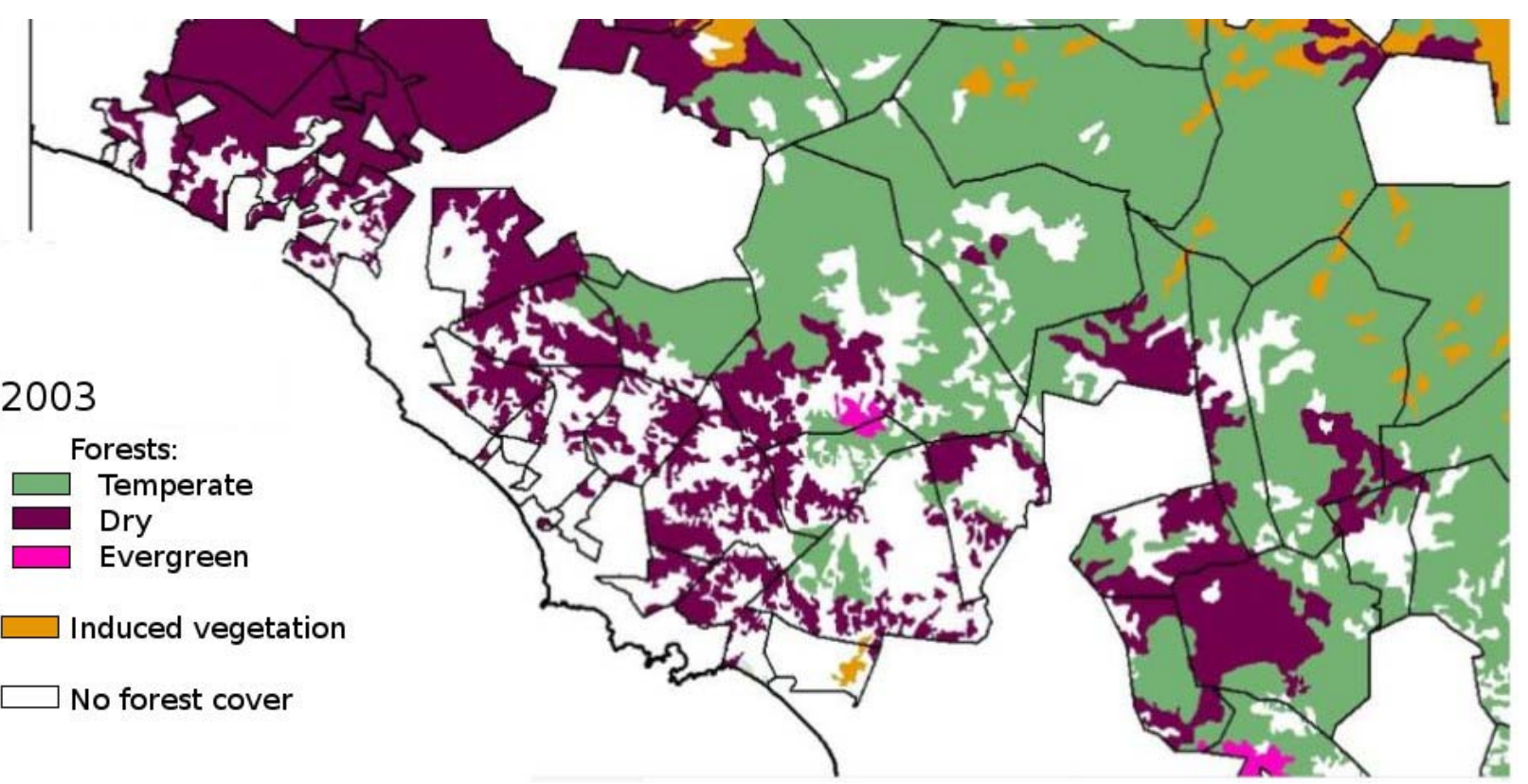

Fig. 3 Vegetation coverage in Costa Grande of Guerrero, 2003. 
The Challenge of Crafting Institutions for the Commons: The Case of

Community Forestry Support Programs in Mexico 2003-2008

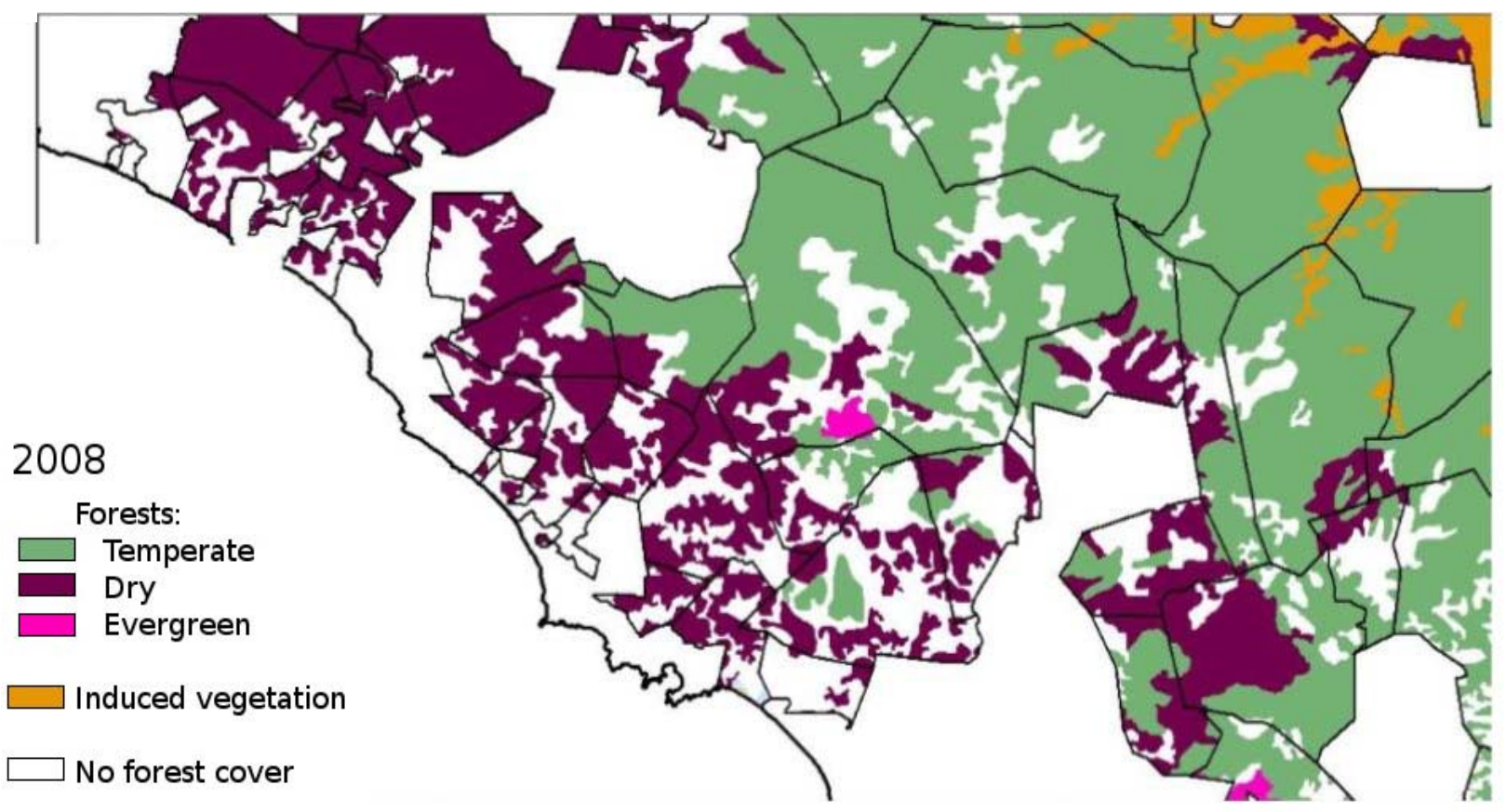

Fig. 4 Vegetation coverage in Costa Grande of Guerrero, 2008.

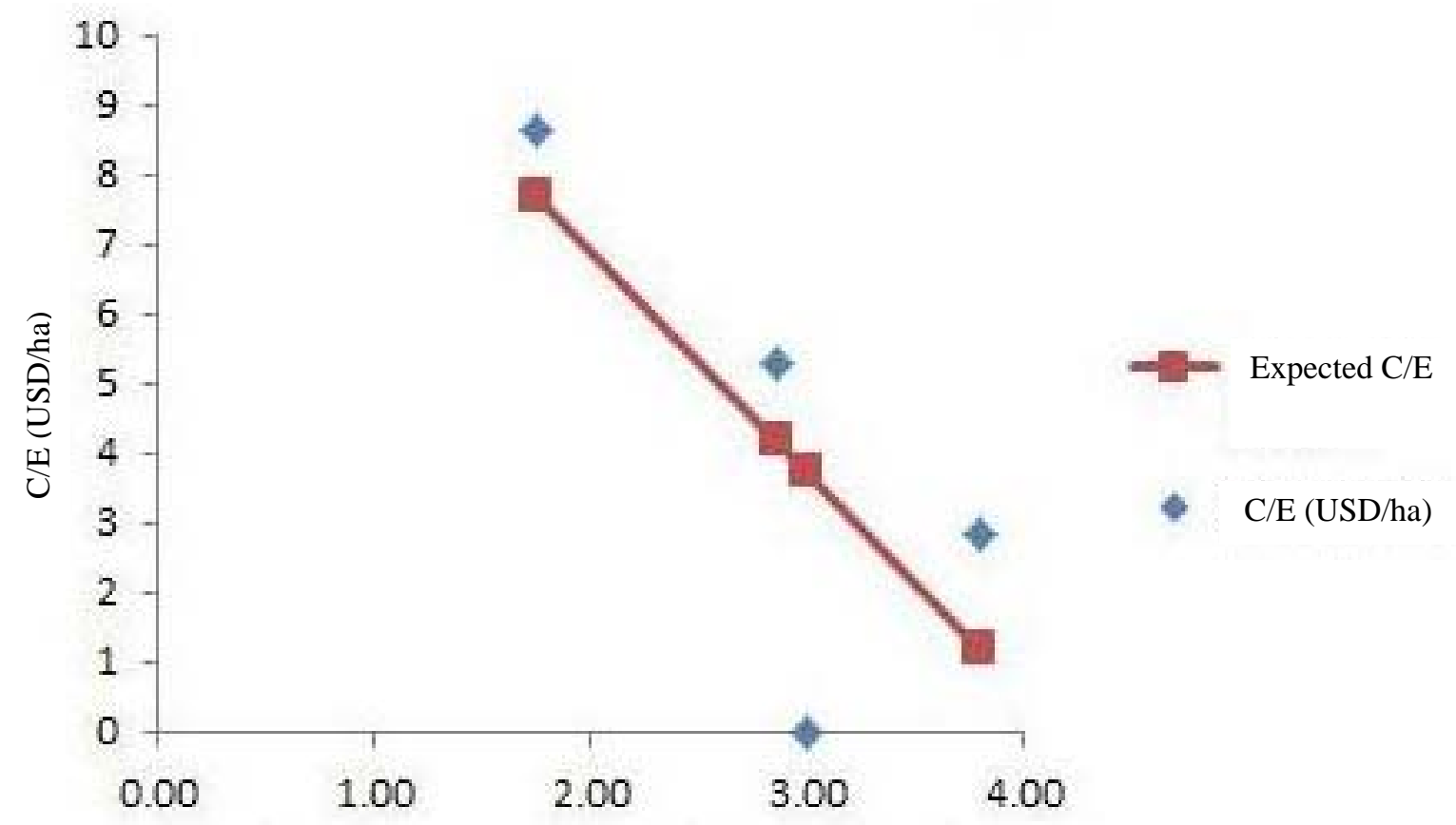

Social Organization and Collective Action Index (SOCAI)

Fig. 5 Correlation between C/E ratio and SOCAI.

Source: regression analysis. ${ }^{* *}$ SOCAI showed a highly significant correlation to $\mathrm{C} / \mathrm{E}$ ratio at $P<0.1$. 
Table 5 C/E for different programs and no programs community.

\begin{tabular}{lll}
\hline Program & Forest cover change/year & C/E (US \$/ha) \\
\hline CBM & $-0.08 \%$ & 8.61 \\
PROCYMAF & $0.50 \%$ & 2.83 \\
COINBIO & $0.52 \%$ & 5.50 \\
NPAs & $0.46 \%$ & 5.30 \\
\hline
\end{tabular}

Source: based on field data and programs official documents.

Table 6 SOCAI and C/E ratio for the programs studied.

\begin{tabular}{lll}
\hline Program & SOCAI & C/E ratio \\
\hline PROCYMAF & 3.80 & 2.83 \\
COINBIO & 6.33 & 5.50 \\
CBM & 1.75 & 8.61 \\
NPAs & 2.86 & 5.30 \\
\hline
\end{tabular}

Ostrom et al. [23] suggested a framework to systematically analyze these communal institutions. The author's results, in particular the association of social organization and collective action with conservation effectiveness and better $\mathrm{C} / \mathrm{E}$ ratios, confirm these ideas. Disengaging local communities from managing the resources base they depend on, as happens when governments take over the control of some areas because of its biological importance, can in fact increase the loss rate. Bray et al. [24] found that in the Guatemala and Mexico Maya forest, deforestation rates were higher in NPAs when compared to community managed high-diversity forest areas. In a more comprehensive study, Porter-Bolland et al. [25] analyzed 40 NPAs and 33 community forest management (CFM) cases in world tropical areas and also found that forest loss rates were higher in NPAs as compared with CFM. But, not in all cases, community management has been as effective. Nolte et al. [26] analyzed 292 protected areas and found that on average, strict protected areas produced less deforestation rates than areas under communities use. They pointed that this clearly changes with deforestation pressures, as they observed better conservation performance of community managed areas when deforestation pressures were higher.

By including a comprehensive empirical data base and more precise indicators about the institutions in work within different environmental, cultural and institutional set-ups, this study contributes to explain why government-led conservation areas have performance problems and also suggest the kind of engagement communities need to become effective stewards of biological diversity.

In a global perspective, we can consider that this study included mostly high deforestation pressure situations. It will be interesting in the future to compare how communal institutions perform under different deforestation pressures in different countries.

\section{Conclusions and Recommendations}

This study shows the effectiveness of most community forestry-related programs in Mexico in conserving forest cover, perhaps its associated biological and cultural diversity, and the flow of services and forest goods provided to the neighboring communities, which means the livelihoods of about 21 million people and most of them indigenous or with an indigenous background.

The relative low success of CBM, shown on its high $8.61 \mathrm{USD} / \mathrm{ha}$, can be explained in institutional terms because of its lack of "promoters of social capital”. In particular, its lack of livelihoods enhancement as primary goal and low local communities incidence in governance bodies, can be seen as factors of lower SOCAI and the associated decrease in its $\mathrm{C} / \mathrm{E}$ ratio.

The better forest conservation outcomes were 
observed in communities with COINBIO presence, as is the case of Costa Grande of Guerrero state, where gains in vegetation cover were observed within the time frame of this study. Therefore, it is important to consider the contribution of this program for better socio-environmental policies, in spite of its lower $\mathrm{C} / \mathrm{E}$ ratio, compared with PROCYMAF.

As shown in the institutional design analysis, one of the main differences between PROCYMAF and COINBIO is that COINBIO included all "promoters of social capital" and supported to new community initiatives in particular. This feature means that COINBIO needed to operate in circumstances where more investment in social capital was needed, while PROCYMAF typically operated in places where civil society organizations were supported by foundations and previously invested in social capital formation. Estimating the cost investing in social capital for PROCYMAF may yield a more realistic evaluation of its $\mathrm{C} / \mathrm{E}$ ratio, which may get closer to that of COINBIO.

The results of this study suggest that social capital formation is a key factor to explain the effectiveness of community forestry-related programs. Inclusion of promoters of social capital into their institutional design may produce higher SOCAI and therefore better $\mathrm{C} / \mathrm{E}$ ratios.

Unfortunately, it is unclear if community forestry-related programs in Mexico are moving to include more promoters of social capital into their institutional design.

The results also suggest that the national biodiversity strategy can become much more effective, including measures, such as:

(1) Direct consistent funding to a national program with clear promoters of social capital and stringent SOCAI and C/E monitoring and evaluation. Today, Mexico puts hundreds of million dollars for the so-called payment for environmental services program. Similar amounts could be used to increase SOCAI;

(2) Include into ANPs institutional design promoters of social capital with strong and clear policies to devolve biodiversity-rich areas management to forest communities, through co-management schemes, for example, revise CBM institutional design to include promoters of social capital to improve its $\mathrm{C} / \mathrm{E}$ ratio and operate it under a SOCAI and C/E monitoring and evaluation;

(3) Increase public funds to community forestry-related programs with high performance. One way to do this without increasing net public expenses or taxes may be to reduce some subsidies that are not too progressive and use them rather to finance a national fund for community forestry-related projects evaluated by their SOCAI and C/E ratio.

Social capital is a key factor of productive forest land conservation, the recent trend in Mexico to collective forest land privatization is a big concern to the existence of forests in the country, as long as this process means the dissolution of commons. An effective forest policy in Mexico should make a clear commitment to keep, increase and revitalize forest commons.

\section{References}

[1] Whitmore, T. M., and Turner, B. L. 2001. Cultivated Landscapes of Middle America on the Eve of Conquest. Oxford, UK: Oxford University Press.

[2] Yannakakis, Y. 2008. The Art of Being in-between: Native Intermediaries, Indian Identity and Local Rule in Colonial Oaxaca. Durham: Duke University Press.

[3] Gilly, A. 2006. The Mexican Revolution. New York: The New Press.

[4] Klooster, D. 1999. "Community-Based Forestry in Mexico: Can It Reverse Processes of Degradation?” Land Degradation \& Development 10 (4): 365-81.

[5] Rights and Resources Initiative. 2015. "Tenure Data Tool.” Accessed May 23, $2015 . \quad$ http://www. rightsandresources.org/resources/tenure-data/tenure-datatool/.

[6] Cubbage, F. W., Davis, R. R., Paredes, D. R., Mollenhauer, R., Elsin, Y. K., Frey, G. E., Hernández, I. A. G., Hurtado, H. A., Cruz, A. M. S., and Salas, D. N. C. 2015. "Community Forestry Enterprises in Mexico: Sustainability and Competitiveness." Journal of Sustainable Forestry 34 (6-7): 623-50. 
[7] Bray, D. B., Merino-Pérez, L., Negreros-Castillo, P., Segura-Warnholtz, G., Torres-Rojo, J. M., and Vester, H. F. M. 2003. "Mexico's Community-Managed Forests as a Global Model for Sustainable Landscapes.” Conservation Biology 17 (3): 672-7.

[8] World Bank. 2000. “Appraisal Document on a Proposed Global Environment Facility Grant in the Amount of SDR 5.8 Million (US \$7.5 Million Equivalent) to Nacional Financiera, S.N.C. for an Indigenous and Community Biodiversity Conservation Project in Mexico." The World Bank Report No. 21150-ME. Accessed May 23, 2015. http://go.worldbank.org/ RAZR1WVFP0.

[9] World Bank. 2000. “Appraisal Document on a Proposed Grant from the Global Environment Facility Trust Fund in the Amount of SDR 11.5 Million to Nacional Financiera, S.N.C. for a Mexico Mesoamerican Biological Corridor Project.” The World Bank Report No. 21136-ME. Accessed May 23, 2015. http://tinyurl.com/corredor-PAD.

[10] World Bank. 2003. “Appraisal Document on a Proposed Loan in the Amount of US \$21.3 Million to the United Mexican States for the Second Community Forestry Project.” The World Bank Report No. 26644. Accessed May 23, 2015. http://go.worldbank.org/ 4UB73AK7X0.

[11] World Bank. 2008. "Implementation Completion and Results Report on a GEF Trust Fund Grant in the Amount of USD 7.5 Million to the United Mexican States for an Indigenous and Community Biodiversity Conservation Project.” The World Bank Report No. ICR0000851. Accessed May 23, 2015. http://documents.worldbank.org/ curated/en/2008/12/10423891/mexico-indigenous-comm unity-biodiversity-conservation-project-coinbio.

[12] World Bank. 2009. "Implementation Completion and Results Report on a Loan in the Amount of US \$21.3 Million to the United Mexican States for the Second Community Forestry Project (Ibrd-72070).” The World Bank Report No. ICR00001093. Accessed May 23, 2015. http://documents.worldbank.org/curated/en/2009/06/1144 8977/mexico-second-community-forestry-project.

[13] World Bank. 2010. “Implementation Completion and Results Report (TF-24371) on a Grant in the Amount of SDR 11.5 Million (US \$14.84 Million Equivalent) to Nacional Financera, S.N.C. for a Mexico Mesoamerican Biological Corridor Project.” The World Bank Report No. ICR1329. Accessed May 23, 2015. http://documents.worldbank.org/curated/en/2015/07/1282 0898/mexico-mesoamerican-biological-corridor-project.

[14] Ostrom, E. 2007. "Institutional Rational Choice: An Assessment of the Institutional Analysis and Development Framework." In Theories of the Policy Process, 2nd ed., edited by Sabatier, P. A. Cambridge, MA: Westview Press, 21-64.

[15] Ostrom, E. 2011. "Background on the Institutional
Analysis and Development Framework.” Policy Studies Journal 39 (1): 7-27.

[16] Ostrom, E., and Basurto, X. 2011. "Crafting Analytical Tools to Study Institutional Change.” Journal of Institutional Economics 7 (3): 317-43.

[17] Instituto Nacional de Estadística, Geografía e Informática (INEGI). 2008. "Land Use and Vegetation Vectorial Data Set Series III, Scale 1:250000.” INEGI, Aguascalientes, Mexico. (in Spanish)

[18] Instituto Nacional de Estadística, Geografía e Informática (INEGI). 2010. "Land Use and Vegetation Vectorial Data Set Series IV, Scale 1:250000.” INEGI, Aguascalientes, Mexico. (in Spanish)

[19] Ostrom, E. 1998. "The International Forestry Resources and Institutions Research Program: A Methodology for Relating Human Incentives and Actions on Forest Cover and Biodiversity." In Forest Biodiversity in North, Central and South America and the Caribbean: Research and Monitoring, edited by Dallmeier, F., and Comiskey, J. A. Vol. 22. Carnforth, Lancashire, UK: Unesco and the Parthenon Publishing Group, 1-28.

[20] Varughese, G. 2000. "Population and Forest Dynamics in the Hills of Nepal: Institutional Remedies by Rural Communities.” In People and Forests: Communities, Institutions and Governance, edited by Gibson, C., McKean, M., and Ostrom, E. Cambridge, Massachusetts: The MIT Press.

[21] Ostrom, E., Gardner, R., and Walker, J. 1994. Games, Rules and Common-Pool Resources. Ann Arbor: University of Michigan Press.

[22] Agrawal, A., and Gibson, C. C. 1999. "Enchantment and Disenchantment: The Role of Community in Natural Resource Conservation.” World Development 27 (4): 629-49.

[23] Ostrom, E., Burger, J., Field, C. B., Norgaard, R. B., and Policansky, D. 1999. "Revisiting the Commons: Local Lessons, Global Challenges.” Science 284 (5412): 278-82.

[24] Bray, D. B., Duran, E., Ramos, V. H., Mas, J. F., Velazquez, A., McNab, R. B., Barry, D., and Radachowsky, J. 2008. "Tropical Deforestation, Community Forests and Protected Areas in the Maya Forest.” Ecology and Society 13 (2): 56.

[25] Porter-Bolland, L., Ellis, E. A., Guariguata, M. R., Ruiz-Mallén, I., Negrete-Yankelevich, S., and Reyes-García, V. 2012. "Community Managed Forests and Forest Protected Areas: An Assessment of Their Conservation Effectiveness across the Tropics.” Forest Ecology and Management 268: 6-17.

[26] Nolte, C., Agrawal, A., Silvius, K. M., and Soares-Filho, B. S. 2013. “Governance Regime and Location Influence Avoided Deforestation Success of Protected Areas in the Brazilian Amazon." Proc. of the National Academy of Sciences 110 (13): 4956-61. 